\title{
PENGARUH STUDENT COMPANY TERHADAP KOMPETENSI KEWIRAUSAHAAN SISWA SEKOLAH MENENGAH KEJURUAN DI DAERAH ISTIMEWA YOGYAKARTA
}

\author{
Sulas $\mathrm{mi}^{1}$ dan Moerdiyanto ${ }^{2}$ \\ ${ }^{1}$ Prestasi Junior Indonesia, ${ }^{2}$ Universitas Negeri Yogyakarta \\ lasmi.elfaty@yahoo.co.id; murdiyanto_351@yahoo.com
}

\begin{abstract}
The purpose of the research is to describe Student Company program and its effect on entrepreneurial competencies of vocational high school students in Yogyakarta. This research is expost facto study. The research was conducted at SMK 1 Depok, SMK 2Depok, SMK 1 Godean, SMK 7 Yogyakarta and SMK 1 Seyegan. Data collection techniques were questionnaires and observation. The data was analyzed using descriptive analysis and multiple linear regression. The results of this study were: (1) Student company was effective to improve the entrepreneurship competencies of vocational high school students in Yogyakarta. The effectiveness of planning aspects was in excellent category (42.11\%), the implementation aspects was in the good category (35.79\%), and the effectiveness of the controls was in the good category (48.42\%). (2) Entrepreneurship competencies of students who took SC were in the good category (56.84\%). (3) The planning aspect of student company has significant effect on the entrepreneurship competencies of students $(t=2.954$;:Sig $=0.004)$. (4) The implementation aspects have significant effect on the entrepreneurship competencies of students ( $t=$ 3.627;Sig=0.000). (5) The control aspect does not have significant effect on the entrepreneurship competencies of students ( $t=0.573$;Sig $=0.568)$. (6) The aspects of planning, implementation, and control simultaneously have a significant effects on the entrepreneurship competence of vocational high school students in Yogyakarta $(F=8.755$; Sig $=0.000)$.
\end{abstract}

Keywords: Entrepreneurship, Student Company, Students Entrepreneurship Competencies

\begin{abstract}
ABSTRAK
Penelitian ini bertujuan untuk mendeskripsikan program student company dan pengaruhnya terhadap kompetensi berwirausaha siswa SMK di Daerah Istimewa Yogyakarta. Penelitian ini merupakan penelitian espost facto. Penelitian dilaksanakan di SMKN 1 Depok, SMKN 2 Depok, SMKN 1 Godean, SMKN 7 Yogyakarta dan SMKN 1 Seyegan. Pengumpulan data menggunakan angket dan observasi. Analisis data dilakukan dengan teknik analisis deskriptif dan regresi linear ganda. Hasil penelitian ini adalah: (1) Student company efektif untuk meningkatkan kompetensi berwirausaha siswa. Ditemukan bahwa efektivitas perencanaan tergolong sangat baik (42,11\%), efektivitas pelaksanaan tergolong baik $(35,79 \%)$, dan efektivitas pengendalian tergolong sangat baik $(48,42 \%)$. (2) Kompetensi wirausaha siswa anggota $S C$ tergolong baik $(56,84 \%)$. (3) Aspek perencanaan berpengaruh signifikan terhadap kompetensi wirausaha siswa $(\mathrm{t}=2,954 ; \mathrm{Sig}=0,004)$. (4) Aspek pelaksanaan berpengaruh signifikan terhadap kompetensi wirausaha siswa $(\mathrm{t}=3,627 ; \mathrm{Sig}=0,000)$. (5) Aspek pengendalian tidak berpengaruh terhadap kompetensi wirausaha siswa $(t=0,573$; Sig. $=0,568)$. (6) Aspek perencanaan, pelaksanaan dan pengendalian $S C$ secara simultan mempunyai pengaruh signifikan terhadap kompetensi wirausaha siswa SMK di DIY $(\mathrm{F}=8,755 ; \mathrm{Sig}=0,000)$
\end{abstract}

Kata kunci : Program Pendidikan Kewirausahaan, Student Company, Kompetensi Kewirausahaan Siswa

\section{PENDAHULUAN}

Menurut UU Sisdiknas Tahun 2003 No. 20 Pasal 15, pendidikan kejuruan merupakan pendidikan menengah yang mempersiapkan peserta didik terutama untuk bekerja dalam bidang tertentu. Pendidikan kejuruan akan efektif apabila siswa diperkenalkan dengan situasi nyata untuk berfikir, bersikap, berperilaku seperti halnya pekerja di industri atau di tempat kerja lainnya.

Menurut Adhikary (2005) dalam (Putu Sudira, 2012:13) menjelaskan bahwa pendidi- 
kan kejuruan adalah pendidikan yang dirancang untuk mengembangkan keterampilan, kecakapan, pemahaman, sikap, kebiasaan-kebiasaan kerja dan apresiasi yang dibutuhkan siswa untuk memasuki dunia kerjanya kelak. Pembelajaran di sekolah menengah kejuruan (SMK) yang tepat adalah pembelajaran yang mampu meningkatkan keterampilan dan kecakapan yang akan digunakan siswa untuk bekerja.

Pendidikan kejuruan berorientasi pada pengembangan proses dan hasil pembelajaran. Tidak hanya kebutuhan belajar di sekolah, tetapi kualitas lulusan menjadi tolok ukur keberhasilan pendidikan kejuruan. Hal ini senada dengan pendapat Finch (1999:14) yaitu:

The ultimate success of a vocational and technical curriculum is not measured merely through student educational achievement but trough the result of that achievementresult that take the form of performance in th work world. Thus, the vocational and technical curriculum is oriented toward process (experience and activities within the school setting) and product (effect of these experiences and activities on former student).

Pendidikan kejuruan merupakan penyelenggaraan jalur pendidikan formal yang dilaksanakan pada jenjang pendidikan tingkat menengah yang bentuk satuan pendidikannya adalah SMK. SMK memiliki berbagai bidang keahlian tertentu yang dipilih oleh siswa sesuai dengan minat, bakat dan potensi yang ada pada diri siswa untuk bekal menuju dunia kerja. Oleh karena itu, siswa SMK yang sudah dibekali keterampilan tersebut, juga perlu diberikan pendidikan kewirausahaan untuk menumbuh kembangkan jiwa dan kompetensi wirausaha pada siswa.

Pendidikan kewirausahaan menjadi penting diberikan kepada anak sejak dini mengingat maraknya budaya instan pada anakanak dan remaja di masa sekarang. Kondisi ini akan memperparah budaya bangsa yang telah menderita karena beberapa kasus diberbagai sektor. Padahal generasi muda mempunyai peran yang strategis dalam memajukan bangsa, dimana keberhasilan bangsa di masa depan tergantung pada kontribusi generasi muda. Oleh karena itu generasi muda perlu diberikan pendidikan kewirausahaan dalam rangka membangun kemandirian diri dan bangsa Indonesia.

Nilai-nilai kewirausahaan dapat diintegrasikan untuk meningkatkan kompetensi kewirausahaan yang sesuai dengan perkembangan siswa SMK. Adapun implementasi nilai-nilai kewirausahaan tersebut antara lain: (1) mandiri, (2) kreatif, (3) berani mengambil resiko dan bertanggungjawab, (4) berorientasi pada tindakan untuk mewujudkan gagasan, (5) kepemimpinan, (6) kerja keras, (7) Penguasaan konsep kewirausahaan, dan (8) Skilsl atau keterampilan dalam menjalankan usaha. (Pusat Kurikulum Balitbang Kemendiknas, 2010:5354). Dengan demikian pendidikan kewirausahaan dapat meningkatkan kompetensi kewirausahaan siswa.

Kompetensi wirausaha ditentukan oleh pengetahuan dan pengalaman usaha. Menurut Gibb (1990:21), define competence as "an ability to perform certain tasks for which knowledge, skills, attitudes, and motivation are necessary. artinya kompetensi adalah sebuah kemampuan untuk menjalankan pekerjaan dengan bekal pengetahuan, keterampilan, sikap dan motivasi. Kompetensi kewirausahaan dibutuhkan ketika seseorang akan menjadi seorang wirausaha.

Menurut Zimmerer (1993:5) kewirausahaan adalah

An entrepreneur is one who creates a new business in the face of risk and uncertainty for the purpose of achieving profit and growth by identifying opportunities and asembling the necessary resources to capitalze on those opportunities.

Wirausahawan adalah orang-orang yang memiliki kemampuan melihat dan menilai kesempatan-kesempatan bisnis; mengumpulkan sumber daya-sumber daya yang dibutuhkan untuk mengambil tindakan yang tepat, mengambil keuntungan serta memiliki sifat, 
watak dan kemauan untuk mewujudkan gagasan inovatif kedalam dunia nyata secara kreatif dalam rangka meraih meningkatkan pendapatan.

Dewasa ini pendidikan kewirausahaan dimasukkan dalam setiap jenjang pendidikan termasuk SMK. Salah satu program pendidikan kewirausahaan adalah Student Company (SC). Student company merupakan salah satu program pendidikan kewirausahaan dengan cara membentuk perusahaan (company) siswa. Para siswa dilatih untuk menjadi pemimpin perusahaan seperti direktur utama (CEO), direktur keuangan (CFO) dan posisi penting lainnya. Dengan begitu, anak-anak memiliki bekal informasi berbisnis seperti teori kepemimpinan, perencanaan bisnis, proses pengambilan keputusan, studi pasar dan implementasinya. Bahkan, anak-anak tersebut akan diberi 'modal' untuk memilih jenis produk/ jasa yang paling sesuai untuk mereka (PJI, 2012:4).

Program student company bertujuan untuk mengembangkan kompetensi wirausaha siswa. Skill atau kompetensi yang menjadi sasaran antara lain kompetensi perakitan atau pembuatan produk, menganalisa dan menginterpretasikan informasi, brainstorming, membangun konsensus, membaca secara kritis, mengumpulkan dan mengorganisir informasi, penilaian diri dan kelompok, interpretasi persediaan produksi, komunikasi secara lisan dan tertulis, melakukan penelitian dan pengamatan, analisa produk, berbicara di depan umum, penelitian, mengevaluasi informasi, menjual, dan bekerja dalam kelompok (PJI, 2012:8).

Program Student Company yang telah terlaksana di Yogyakarta sejauh ini belum dinilai efeknya terhadap kompetensi kewirausahaan siswa. Efektivitas program student company dilihat dari fungsi manajemen pengelolaannya. Menurut Nagendra (2008:4):

Management is the process of planning, organizing, leading and controlling the efforts of the organization members and using all organizational resources to achieve related organizational goals.

Manajemen merupakan sebuah proses perencanaan, pengorganisasian, kepemimpinan dan pengawasan untuk semua anggota perusahaan dan semua sumberdaya untuk mencapai tujuan yang telah ditentukan. Dalam pedoman manajemen unit produksi (Depdiknas, 2007:25) disebutkan bahwa manajemen ini dapat lebih disederhanakan menjadi Perencanaan, Pelaksanaan, dan Pengendalian (P3).

Berdasarakan pada uraian di atas maka penelitian ini berfokus untuk melihat efek atau pengaruh dari program Student Company terhadap kompetensi kewirausahaan siswa yang telah terlibat di dalamnya. Penelitian tentang program Student Company ini perlu dilakukan untuk melihat manajemen pengelolaan student company yang terdiri dari aspek perencanaan, pelaksanaan dan pengendalian, sehingga dapat diperoleh informasi yang berguna sebagai referensi pengembangan program-program yang mendukung peningkatan kompetensi kewirausahaan siswa. Dengan meningkatnya kompetensi kewirausahaan siswa diharapkan menjadi generasi pengusaha muda mandiri untuk kemajuan bangsa.

\section{METODE}

Jenis penelitian ini adalah ekspost facto. Penelitian ini didesain untuk mengetahui pengaruh student company terhadap kompetensi kewirausahaan siswa. Pengumpulan data menggunakan angket dan observasi. Analisis data dilakukan dengan teknik deskriptif dan regresi linear.

Penelitian ini dilaksanakan pada Desember 2013 sampai dengan Mei 2014. Penelitian ini dilaksanakan di SMKN 1 Depok, SMKN 2 Depok, SMKN 1 Godean, SMKN 7 Yogyakarta dan SMKN 1 Seyegan.

Populasi dalam penelitian ini adalah 5 SMK yang telah menerapkan program Student Company. Setiap SC mempunyai 19 anggota, jadi total seluruh populasi penelitian ini adalah 95 siswa. Penelitian ini termasuk dalam 
penelitian populatif karena semua anggota populasi menjadi subyek penelitian (Arikunto, 2006:112).

Sebelum dilaksanakan penelitian dilakukan dulu penyusunan instrumen berupa kuesioner. Untuk mendapatkan kuisoner yang baik maka dilakukan uji validitas dan reliabilitas (Sukardi, 2003:121). Validitas isi dengan rasional judgement expert, kemudian dilakukan uji coba validitas konstruk dengan uji coba di lapangan. Reliabilitas instrumen dalam penelitian ini adalah dengan uji statistik Cronbach Alpha $(\alpha)$.

Prosedur penelitian dilakukan dengan melakukan pengumpulan data menggunakan kuesioner dengan skala Likert yang terdiri dari empat pilihan jawaban yaitu: $\mathrm{SS}=$ sangat setuju, $\mathrm{S}=$ setuju, $\mathrm{TS}=$ tidak setuju dan $\mathrm{STS}=$ sangat tidak setuju.

Kuesioner digunakan untuk memperoleh informasi dari responden penyelenggaraan Student Company serta untuk mengetahui kompetensi kewirausahaan siswa. Kemudian data yang sudah diperoleh dianalisis data menggunakan teknik analisis deskriptif kuantitatif yaitu dengan cara menganalisis data dengan statistik deskriptif kemudian mendeskripsikannya dalam bentuk tabel dan grafik. Setelah analisis deskriptif, kemudian dilakukan analiss regresi ganda menggunakan SPSS 17.0.

Tabel 1. Kriteria Kecenderungan Variabel

\begin{tabular}{ll}
\hline Kriteria & Rentang Skor \\
\hline Sangat Baik & $\mathrm{M}+1,5 \mathrm{SD}$ keatas \\
Baik & $\mathrm{M}$ sampai $\mathrm{M}+1,5 \mathrm{SD}$ \\
Cukup Baik & $\mathrm{M}-1,5 \mathrm{SD}$ sampai $\mathrm{M}$ \\
Kurang Baik & $\mathrm{M}-1,5 \mathrm{SD}$ kebawah
\end{tabular}

(Sutrisno, 1986:38).

Regresi berganda digunakan untuk melihat pengaruh perencanaan, pelaksanaan, dan pengendalian program student company baik secara parsial maupun simultan terhadap kompetensi kewirausahaan siswa. Menurut
Sugiyono (2003:22) rumus regresi dengan tiga prediktor adalah :

$$
Y=a+b_{1} X_{1}+b_{2} X_{2}+b_{3} X_{3}
$$

Keterangan:

$\mathrm{Y}=$ kriterium

$\mathrm{a}=$ konstanta

$\mathrm{b}=$ koefisien regresi dari tiap-tiap variabel independen.

$\mathrm{X}=$ predictor

$\mathrm{X}_{1}=$ perencanaan Student Company

$\mathrm{X}_{2}=$ pelaksanaan Student Company

$\mathrm{X}_{3}=$ pengendalian Student Company

\section{HASIL DAN PEMBAHASAN}

Pada penelitian ini terdapat tiga variabel independen, yaitu perencanaan $\mathrm{SC}\left(\mathrm{X}_{1}\right)$, pelaksanaan SC $\left(\mathrm{X}_{2}\right)$, pengendalian $\mathrm{SC}\left(\mathrm{X}_{3}\right)$ dan satu variabel dependent, yaitu kompetensi kewirausahaan (Y). Sebelum dilakukan analisis lebih lanjut, terlebih dahulu dilakukan analiss deskrptif. Berikut adalah analisis deskriptif masing-masing variabel.

Tabel 2. Nilai Batasan Dalam Menentukan Kriteria dari Masing-Masing Variabel

\begin{tabular}{lrrrr}
\hline \multicolumn{1}{c}{ Hasil Analisis } & \multicolumn{1}{c}{$\mathrm{X}_{1}$} & \multicolumn{1}{c}{$\mathrm{X}_{2}$} & $\mathrm{X}_{3}$ & \multicolumn{1}{c}{$\mathrm{Y}$} \\
\hline Mean & 22,4 & 60,2 & 22,1 & 66,5 \\
Median & 23 & 61 & 22 & 66 \\
Mode & 21 & 50 & 21 & 63 \\
Std. Deviation & 3,1 & 10,9 & 3,4 & 8,8 \\
Minimum & 14 & 40 & 14 & 40 \\
Maximum & 28 & 83 & 28 & 86 \\
\hline
\end{tabular}

Berdasarkan nilai batasan yang telah ditentukan pada Tabel 2 di atas, maka dapat dibuat tabel skor kriteria dari masing-masing variabel di bawah ini.

Tabel 3. Efektivitas Perencanaan SC

Interval Kelas $\% \quad$ Kategori

\begin{tabular}{lcl}
\hline $24,5 \leq X$ & 42,11 & Sangat Baik \\
$21 \leq X<24,5$ & 35,79 & Baik \\
$17,5 \leq X<21$ & 13,68 & Cukup \\
$X<17,5$ & 8,42 & Kurang \\
\hline
\end{tabular}


Kategorisasi perencanaan $S C$ dapat disajikan dalam bentuk histogram sebagai berikut:

Efektivitas perencanaan Student Company (Business Plan)

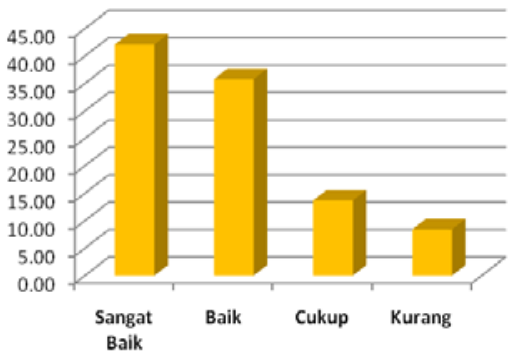

$=$ Prosentase $(\%$

Gambar 1. Histogram Perencanaan SC

Tabel 4. Efektivitas Pelaksanaan SC

\begin{tabular}{lrl}
\multicolumn{1}{c}{ Interval Kelas } & $\%$ & \multicolumn{1}{c}{ kategori } \\
\hline $72,25 \leq \mathrm{X}$ & 16,84 & Sangat Baik \\
$61,5 \leq \mathrm{X}<72,25$ & 35,79 & Baik \\
$51 \leq \mathrm{X}<61,5$ & 17,89 & Cukup \\
$\mathrm{X}<51$ & 29,47 & Kurang \\
\hline
\end{tabular}

Adapun histogram dari pelaksanaan student company adalah sebagaimana berikut:

Efektivitas pelaksanaan Student Company

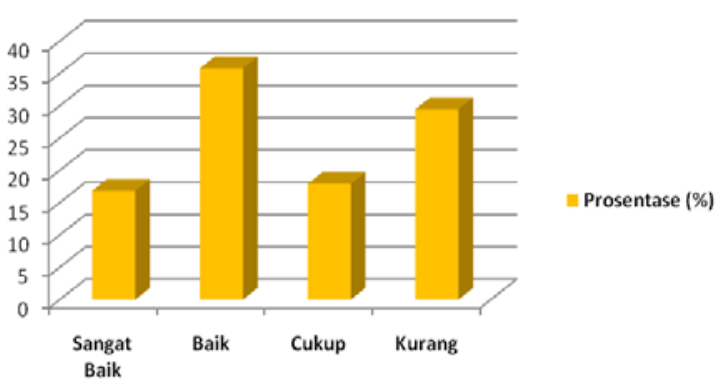

Gambar 2. Diagram Batang Pelaksanaan SC

Tabel 5. Efektivitas Pengendalian

\begin{tabular}{lcl}
\multicolumn{1}{c}{ Interval Kelas } & $\%$ & Kategori \\
\hline $24,5 \leq X$ & 26,32 & Sangat Baik \\
$21 \leq X<24,5$ & 48,42 & Baik \\
$17,5 \leq X<21$ & 12,63 & Cukup \\
$X<17,5$ & 12,63 & Kurang \\
\hline
\end{tabular}

Kategorisasi pengendalian Student Company dapat disajikan dengan histogram sebagai berikut:

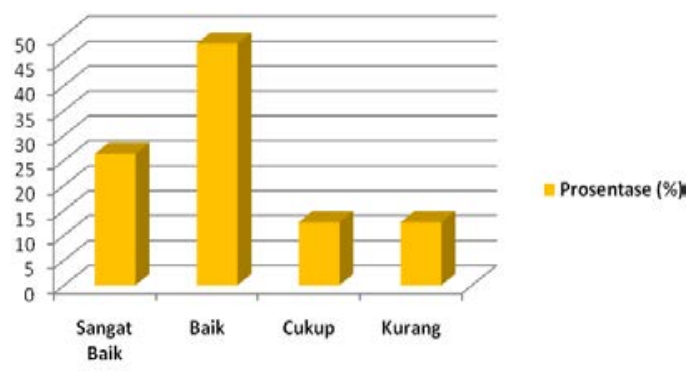

Gambar 3. Histogram Pengendalian SC

Tabel 6. Kompetensi Kewirausahaan (Y)

\begin{tabular}{lcl}
\hline \multicolumn{1}{c}{ Interval Kelas } & $\mathbf{\%}$ & kategori \\
\hline $74,5 \leq \mathrm{X}$ & 21,05 & Sangat Baik \\
$63 \leq \mathrm{X}<74,5$ & 56,84 & Baik \\
$51,5 \leq \mathrm{X}<63$ & 15,79 & Cukup \\
$\mathrm{X}<51,5$ & 6,32 & Kurang \\
\hline
\end{tabular}

Adapun histogram dari kompetensi kewirausahaan siswa adalah sebagai berikut:

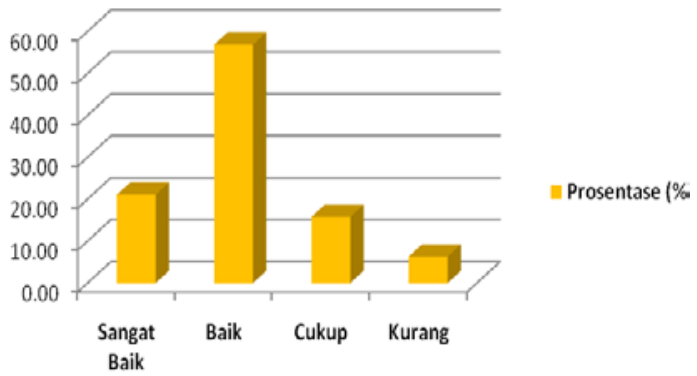

Gambar 4. Histogram Kompetensi Kewirausahaan Siswa SC

\section{Program Student Company dan Kompetensi Ke wiraus ahaan Sis wa}

Analisis deskriptif pada setiap aspek student company yakni meliputi aspek perencanaan, pelaksanaan dan pengendalian.

Dari Tabel 3 dan Gambar 1 dapat dijelaskan bahwa perencanaan SC dalam kategor bangat baik sebesar $42,11 \%$; baik sebasar 35,79\%; cukup baik 13,68\% dan kurang baik sebesar $8,42 \%$. Berdasarkan data yang diperoleh tersebut, dapat ditarik kesimpulan 
bahwa perencanaan student company adalah cenderung baik.

Tabel 4 dan Gambar 2 menunjukkan bahwa pelaksanaan student company menunjukkan kategori sangat baik sebesar $16,84 \%$; baik sebesar 35,79\%; cukup baik $17,89 \%$ dan kurang baik sebesar 29,47\%. Berdasarkan data yang diperoleh dapat ditarik kesimpulan bahwa pelaksanaan student company adalah cenderung baik.

Tabel 5 dan Gambar 3 menunjukkan kecenderungan pengendalian SC. Pengendalian student company (business plan) menunjukkan kategori sangat baik sebesar 26,32\%; baik sebasar 48,42\%; cukup baik $12,63 \%$ dan kurang baik sebesar $12,63 \%$. Berdasarkan data yang diperoleh dapat ditarik kesimpulan bahwa pengendalian Student Company adalah cenderung baik.

Tabel 6 dan Gambar 4 menunjukkan kompetensi kewirausahaan dalam kategori sangat baik sebesar $21,05 \%$; baik sebesar $56,84 \%$; cukup baik $15,79 \%$ dan kurang baik sebesar 6,32\%. Berdasarkan data yang diperoleh dapat ditarik kesimpulan bahwa kompetensi kewirausahaan siswa anggota student company adalah cenderung baik.

Adapun rangkuman hasil deskripsi data efektivitas student company adalah sebagai berikut :

Tabel 7. Rangkuman Hasil Deskripsi SC

\begin{tabular}{ccc}
\hline Variabel & \% & Kategori \\
\hline Perencanaan $S C$ & 42,11 & Sangat Baik \\
Pelaksanaan $S C$ & 35,79 & Baik \\
Pengendalian $S C$ & 48,42 & Baik \\
Kompetensi & 56,84 & Baik \\
Wirausaha & & \\
\hline
\end{tabular}

Dari Tabel 7 tersebut di atas menunjukkan bahwa student company dari aspek perencanaan adalah sangat baik dengan prosentase sebesar $42,11 \%$, aspek pelaksanaan termasuk dalam kategori baik dengan prosentase sebesar $35,79 \%$, pengendalian juga termasuk dalam kategori baik dengan prosentase sebesar 48,42\% serta kompetensi wirausaha siswa yang mengikuti SC dalam kategori baik dengan prosentase 56,84. Dari data tersebut dapat disimpulkan bahwa student company efektif untuk program pendidikan kewirausahaan yang dapat meningkatkan kompetensi wirausaha siswa.Adapun kompetensi kewirausahaan siswa meliputi kompetensi teknis produksi (technical competence), kemampuan untuk memasarkan produk yang telah dihasilkan (marketing competence), kemampuan mengelola keuangan (financial competence) dan kemampuan untuk menjalin kerjasama usaha (public relation competence).

\section{Pengaruh Student Company terhadap Kompetensi Ke wiraus ahaan Siswa \\ Pengaruh Student Company terhadap kompetensi kewirausahaan dianalisis menggunakan analisis statistik regresi berganda berbantuan SPSS 17.00.}

\section{Pengaruh Perencanaan Student Company}

Hasil pengujian hipotesis 1 mengenai pengaruh perencanaan student company $\left(X_{1}\right)$ terhadap kompetensi kewirausahaan ditemukan nilai $\mathrm{B}=0,789$ dengan $\mathrm{t}=2,954$ dan $\mathrm{Sig}=0,004$. Oleh karena nilai sig. $<0,05$ maka Ho $(\beta 2=0)$ ditolak yang artinya variabel perencanaan student company $\left(X_{1}\right)$ berpengaruh positif terhadap kompetensi wirausaha jika variabel aspek pelaksanaan dan pengendalian SC dikendalikan/dikontrol.

Nilai B sebesar 0,789 menyatakan bahwa setiap aspek perencanaan mengalami kenaikan sebesar 1\% akan menaikkan kompetensi wirausaha $(Y)$ sebesar 0,789 dengan asumsi aspek pelaksanaan $\left(X_{2}\right)$ dan pengendalian $\left(X_{3}\right)$ tetap. Dengan demikian dapat disimpulkan bahwa perencanaan student company berpengaruh signifikan terhadap kompetensi wirausaha siswa.

\section{Pengaruh Pelaksanaan Student Company}

Hasil pengujian hipotesis 2 mengenai pengaruh pelaksanaan student company $\left(X_{2}\right)$ terhadap kompetensi kewirausahaan ditemukan nilai $\mathrm{B}=0,275$ dengan $\mathrm{t}=3,627$ dan $\mathrm{Sig}=0,000$. 
Oleh karena nilai sig $<0,05$ maka Ho $(\beta 2=0)$ ditolak yang artinya variabel pelaksanaan student company $\left(X_{2}\right)$ berpengaruh signifikan terhadap kompetensi wirausaha jika variabel perencanaan dan pengendalian SC dikendalikan/dikontrol.

Nilai 0,275 menunjukkan bahwa pengaruh pelaksanaan terhadap kompetensi adalah satu arah, artinya setiap variabel aspek pelaksanaan mengalami naik sebesar $1 \%$ maka nilai kompetensi wirausaha akan naik sebesar 0,275 dengan asumsi aspek perencanaan $\left(X_{1}\right)$ dan aspek pengendalian $\left(X_{3}\right)$ tetap. Dengan demikian dapat disimpulkan bahwa efektivitas student company aspek pelaksanaan (business activity) berpengaruh signifikan terhadap kompetensi wirausaha siswa.

\section{Pengaruh Penge ndalian Student Company}

Hasil pengujian hipotesis 3 mengenai pengaruh pengendalian student company $\left(X_{3}\right)$ terhadap kompetensi kewirausahaan ditemukan ditemukan nilai $\mathrm{B}=0,130$ dengan $\mathrm{t}=0,573$ dan $\mathrm{Sig}=0,568$. Oleh karena nilai sig $>0,05$ maka Ho $(\beta 2=0)$ diterima yang artinya variabel efektivitas pengendalian $\left(X_{3}\right)$ tidak berpengaruh signifikan terhadap kompetensi wirausaha jika variabel aspek perencanaan dan pelaksanaan SC dikendalikan/dikontrol.

Nilai B sebesar 0,130 menunjukkan bahwa pengaruh aspek pengendalian terhadap kompetensi wirausaha adalah positif atau searah, artinya jika variabel aspek pengendalian mengalami kenaikan sebesar 1\% maka nilai kompetensi kewirausahaan akan naik sebesar 0,130 dengan asumsi variabel bebas lainnya konstan. Dengan demikian dapat disimpulkan bahwa efektivitas student company aspek pengendalian (controlling) tidak berpengaruh terhadap kompetensi wirausaha siswa.

\section{Pengaruh Perencanaan, Pelaksanaan dan Pengendalian Student Company Secara Simultan}

Hasil pengujian tersebut ditemukan harga $F$ hitung sebesar 8,755 dengan Sig. $=0,00$. Oleh karena nilai sig. $<0,05$ maka Ho $(\rho=0)$ ditolak yang artinya aspek perencanaan (business plan), pelaksanaan dan pengendalian secara simultan memiliki pengaruh yang signifikan terhadap kompetensi wirausaha.

$\mathrm{R}$ Square $=0,224$ menunjukkan angka koefisien determinasinya $\left(R^{2}\right)$. Artinya variansi dalam kompetensi wirausaha dapat dijelaskan oleh aspek perencanaan (business plan), pelaksanaan dan pengendalian melalui model sebesar $22,4 \%$, sisanya $(77,6 \%)$ berasal dari variabel lain. Atau dengan bahasa sederhana besarnya kontribusi/sumbangan aspek perencanaan (business plan), pelaksanaan dan pengendalian terhadap kompetensi wirausaha adalah sebesar $22,4 \%$, sisanya $(77,6 \%)$ berasal dari variabel lain.

Untuk melihat persamaan regresi dari Kompetensi kewirausahaan siswa (Y), perencanaan $\mathrm{SC}\left(\mathrm{X}_{1}\right)$, pelaksanaan $\mathrm{SC}\left(\mathrm{X}_{2}\right)$ dan pengendalian $\mathrm{SC}\left(\mathrm{X}_{3}\right)$ adalah dengan melihat hasil analisis tabel berikut:

Tabel 8. Koefisien Regresi Student Company

\begin{tabular}{|c|c|c|c|c|c|}
\hline \multirow{2}{*}{ Model } & $\begin{array}{l}\text { Unstand } \\
\text { Coeffic }\end{array}$ & $\begin{array}{l}\text { ardized } \\
\text { ients }\end{array}$ & $\begin{array}{l}\text { Standardized } \\
\text { Coefficients }\end{array}$ & \multirow{2}{*}{$\mathrm{t}$} & \multirow{2}{*}{ Sig. } \\
\hline & \multicolumn{3}{|c|}{ Std. } & & \\
\hline 1 (Constant) & 29,789 & 8,044 & & 3,703 & 0,000 \\
\hline Perencanaan & 0,789 & 0,267 & 0,277 & 2,954 & 0,004 \\
\hline Pelaksanaan & 0,275 & 0,076 & 0,339 & 3,627 & 0,000 \\
\hline Pengendalian & 0,130 & 0,226 & 0,053 & 0,573 & 0,568 \\
\hline a. Dependent V & lable: & ompete & ensi Wirausaha & & \\
\hline
\end{tabular}

Adapun persamaan regresi penelitian ini adalah sebagai berikut :

$$
Y^{\prime}=29,789+0,789 X_{1}+0,275 X_{2}+0,130 X_{3}
$$

Dari hasil perhitungan statistik didapat nilai konstanta untuk persamaan regresi sebesar 29,789. Hal ini berarti apabila aspek perencanaan, pelaksanaan dan pengendalian $\mathrm{SC}=0$ maka kompetensi wirausaha adalah sebesar 29,789. Berdasarkan output SPSS, parameter koefisien regresi bertanda positif. Secara matematis, tanda positif berarti setiap perubahan salah satu variabel bebas akan mengakibatkan perubahan variabel terikat dengan arah yang sama bila variabel bebas lainnya dianggap konstan. Dengan demikian 
dapat disimpulkan bahwa efektivitas aspek perencanaan (business plan), pelaksanaan dan pengendalian SC secara simultan memiliki pengaruh yang signifikan terhadap kompetensi wirausaha siswa.

\section{SIMPULAN}

Berdasarkan uraian tersebut, simpulan dari penelitian ini adalah sebagai berikut: (1) Student Company (SC) yang telah terlaksana di SMK Provinsi Daerah Istimewa Yogyakarta secara keseluruhan termasuk dalam kategori baik, dimana perencanaan $S C$ dalam kategori sangat baik, pelaksanaan $S C$ dalam kategori baik, dan pengendalian SC juga dalam kategori baik. (2) Kompetensi kewirausahaan siswa anggota $S C$ termasuk dalam kategori baik. Kompetensi kewirausahaan tersebut antara lain: meliputi kompetensi teknis produksi (technical competence), (technical competition), kemampuan untuk memasarkan produk yang telah dihasilkan (marketing competition), kemampuan mengelola keuangan (financial competition) dan dan kemampuan untuk menjalin kerjasama usaha (public relation). (3) Student Company mempunyai pengaruh yang signifikan terhadap kompetensi kewirausahaan siswa. Perencanaan (business plan) dan pelaksanaan (business activity) $S C$ mempunyai pengaruh yang signifikan terhadap kompetensi wirausaha siswa, tetapi pengendalian (controlling) SC tidak berpengaruh terhadap kompetensi wirausaha. Berdasarkan simpulan di atas, maka saran dari penelitian ini adalah sebagai berikut. (1) Bagi pihak sekolah diharapkan untuk menciptakan lingkungan dan suasana yang mendukung pembelajaran kewirausahaan. Ketersediaan waktu dan tempat hendaknya mendapat kelonggaran agara student company bisa berjalan dengan baik. Selain itu pihak sekolah diharapkan untuk selalu mengikutsertakan para guru dalam pendampingan student company serta memberikan fasilitas, sarana prasarana untuk kelancaran pembelajaran student company. Dukungan sekolah dalam bentuk spiritual dan motivasi juga dibutuhkan oleh siswa dalam menjalankan student company, karena perjalanan sebuah usaha selalu dinamis bersama dengan hambatan-hambatan yang dihadapi oleh siswa. (2) Hendaknya dunia usaha dan dunia industri menjalin kerjasama dengan dunia pendidikan untuk memberikan masukan terhadap kurikulum dan metode pembelajaran yang dibutuhkan oleh DUDI. Selain itu, dana CSR dari DUDI lebih baik jika digunakan untuk sponsor kegiatan pembelajaran seperti student company di sekolah-sekolah untuk meningkatkan kecerdasan kehidupan bangsa. (3) Dalam penelitian ini, untuk meningkatan kompetensi wirausaha menggunakan metode pembelajaran student company. Untuk pengembangan penelitian selanjutnya dapat dilakukan dengan berbagai macam metode yang dapat digunakan agar siswa mempunyai kompetensi wirausaha yang baik.

\section{DAFTAR RUJUKAN}

Arikunto, S. 2006. Prosedur penelitian (suatu pendekatan praktik): Jakarta: Rineka Cipta

Direktorat Pembinaan SMK. 2008. Kajian peranan SMK kelompok teknologi terhadap pertumbuhan industri manufaktur. Jakarta: Direktorat Pembinaan SMK Depdiknas

Dirjen Peningkatan Mutu Tendik. 2007. Pedoman manajemen unit produksi dan jasa sebagai sumber belajar siswa dan penggalian pendanaan pendidikan. Jakarta: Depdiknas

Finch and Curtis R. Crunkilton, John R. 1999. Curriculum development in vocational and technical education planing, content, and implementation (5thed). Bostom: Allyn and Bacom

Gibson, Ivancevich \& Donnelly. 2008. Organisasi, perilaku, struktur, proses. 
(Terjemahan Nunuk Adiarni). Jakarta: Penerbit Binarupa Aksara. (Buku asli diterbitkan 1991)

Nagenda, S \& V.S. Manjunath. 2008. Entreprenurship and management. Bangalore : Saquine Technical Publisher

Pusat Kurikulum Balitbang Kemdiknas. 2010. Pengembangan pendidikan kewirausahaan; bahan pelatihan penguatan metodologi pembelajaran berdasarkan nilainilai budaya untuk membentuk daya saing dan karakter bangsa. Jakarta: Puskurbuk Kemdikbud

Sutrisno, Purnomo. 2005. Pembelajaran kewirausahaan (pedoman guru). Yogyakarta: Penerbit Graha Ilmu
Sudira, Putu. 2012. Filosofi dan teori pendidikan vokasi dan kejuruan. Yogyakarta: UNY Press

Sukardi. 2003. Metodologi penelitian pendidikan kompetensi dan praktiknya. Jakarta : Bumi Aksana

Sugiono. 2008. Metode penelitian kuantitatif kualitatif dan $R \& D$. Bandung : Alfabeta

Yayasan PJI.2012. JA company program: panduan dan lembar kerja siswa. Jakarta: Yayasan PJI

Zimmerer, Thomas W.,Norman Scarborough. 1993. Entrepreneurship the new venture formation. Prentice-Hall International In 